\title{
Phylogenetic analysis of HIV-1 archived DNA in blood and gut-associated lymphoid tissue in two patients under antiretroviral therapy
}

\author{
Patricia Recordon-Pinson ${ }^{1}$, Annie Gosselin ${ }^{2}$, Petronela Ancuta ${ }^{3}$, Jean-Pierre Routy ${ }^{4}$ and Hervé Fleury ${ }^{1,5^{*}}$ (D)
}

\begin{abstract}
One of the approaches to cure human immunodeficiency virus (HIV) is the use of therapeutic vaccination. We have launched the Provir/Latitude 45 study to identify conserved CTL epitopes in archived HIV-1 DNA according to the HLA class I alleles in aviremic patients under antiretroviral therapy (ART). A HIV-1 polypeptidic therapeutic vaccine based on viral sequence data obtained from circulating blood was proposed; here, our aim was to compare the proviral DNA in blood and gut-associated lymphoid tissue (GALT). Peripheral blood mononuclear cells and gut biopsies were obtained from two HIV-1 infected patients under successful antiretroviral therapy. Total DNA was extracted including the proviral DNA. The HIV-1 reverse transcriptase was sequenced in both compartments using next generation sequencing followed by single genome sequencing; phylogenetic trees were established and compared. The proviral sequences of both compartments intra-patient exhibited a very low genetic divergence while it was possible to differentiate the sequences inter-patients; single genome sequencing analysis of two couples of samples confirmed that there was no compartmentalization of the sequences intra-patient. We conclude that, considering these two cases, the proviral DNA sequences in blood and GALT are similar and that the epitope analysis of HIV-1 provirus in blood should be considered as relevant to that observed in the GALT, a hard-to-reach major compartment, and can therefore be used for therapeutic vaccine approaches.
\end{abstract}

Keywords: HIV-1, Proviral DNA, Blood, Gut associated lymphoid tissue (GALT), Phylogenetic comparison of archived viral sequences

\section{Background}

HIV-1 infection can be managed by ART, leading to the control of viral replication and improving the health of people living with HIV. However, ART cannot be interrupted since this would lead to a rebound of viral replication $[1,2]$ as virus establishes cellular (latently infected resting $\mathrm{CD} 4+$ memory $\mathrm{T}$ cells) and anatomical reservoirs very early during infection [3-8]. Gut Associated Lymphoid Tissue (GALT) is considered to be one of the main reservoirs of Simian Immunodeficiency Virus (SIV) and

${ }^{*}$ Correspondence: herve.fleury@u-bordeaux.fr

${ }^{1}$ CNRS UMR 5234, Université de Bordeaux, Bordeaux, France

Full list of author information is available at the end of the article
HIV infection [9-11]. Cure strategies for HIV-1 include therapeutic vaccination [12], although immune response observed was not able to control viral replication after ART discontinuation [13]. In this context, we launched the Provir/Latitude 45 project to identify conserved CTL epitopes in the proviral HIV-1 DNA of patients with long-term ART [14]. The study involves in silico modeling based on the HIV-1 proviral DNA sequences, the HLA alleles and the HIV-1 CTL epitopes following sequencing of the archived DNA from peripheral blood mononuclear cells (PBMC), i.e., from circulating blood. Since our initial work was based on proviral DNA in PBMC, we assessed whether our observations would be the same in another compartment, namely GALT. Herein, we present 
a phylogenetic comparison of the archived HIV-1 DNA in PBMC and GALT from two HIV-1 infected patients at success of ART.

\section{Materials and methods}

The study participants (referenced as patients 5A and 10) were recruited at Centre Hospitalier Universitaire de Montreal (CHUM). They were Caucasian individuals infected with an HIV-1 subtype B and under successful antiretroviral therapy (ART) for more than 4 years. For each patient, a sigmoid biopsy was collected during colonoscopy 4 years after initiation of successful ART and processed as previously described [15]. Matched peripheral blood was collected on the same day and immediately processed with Ficoll for PBMC isolation, performed in parallel with cell extraction from biopsy tissue. DNA was extracted from both compartments and used for next generation sequencing (NGS) analysis of HIV-1 provirus; we used the method already published $[16,17]$ to amplify fragment B, i.e., polymerase (Pol) region including $\mathrm{RT}$ and integrase. The PCR products were purified and quantitated, the library was prepared using the Nextera XT DNA Sample Preparation kit; each individual library was then sequenced on a MiSeq Illumina platform. Raw data (FASTQ files) were submitted to the SmartGene ${ }^{\circledR}$ NGS HIV-1 module to generate a BAM file for each patient and each sample was processed for further analysis [18]. The study was carried out using only the Pol RT part region of the sequences obtained. Using Galaxy and Clustal software, RT gene sequences from the two compartments (GALT and PBMC) were selected for neighbor-joining analysis from matrix distances calculated after gapstripping of alignments, with a Kimura two-parameter algorithm and bootstrap analysis. To do so, an alignment was generated that included only reads with lengths $>400 \mathrm{bp}$ corresponding to a given region of RT (variable according to the patient, from amino-acids 39 to 202). This length limitation explains the small number of reads used for this analysis compared to the total number of reads covering this region. Phylogenetic trees were visualized using Interactive Tree of Life (ITOL) software [19]. Single genome sequencing (SGS) was carried out according to the method of Palmer et al. [20]. The total extracted DNA of both compartments was diluted in TE buffer at a dilution yielding a PCR product in three out of 10 PCRs. In this case, according to Poisson's distribution, the dilution contains one copy of CDNA per positive PCR at about $80 \%$ of the time. Two rounds of PCR for RT amplification were followed by visualization of the PCR products. The 1:9 dilution was found to be optimal for Sanger sequencing and the sequences (assuming that there was no mixture of population) of PBMC and GALT obtained were aligned by Clustal to obtain a neighbor-joining tree. For evaluation of evolutionary divergence, the median, mean and range of the number of base substitutions per site between RT sequences were calculated. Analyses were conducted using the Maximum Composite Likelihood model [21]. The analysis involved 4100 nucleotide sequences. Codon positions included were 1 st +2 nd $+3 r d+$ Noncoding. All positions containing gaps and missing data were eliminated. There was a total of 376 positions in the final dataset. Evolutionary analyses were conducted in Molecular Evolutionary Genetics Analysis (MEGA) 7 software [22].

\section{Results}

The phylogenetic trees are presented in Fig. 1.

NGS analysis of patient $5 \mathrm{~A}$ shows that the sequences from blood and GALT compartments exhibit a low genetic divergence and are located on the same branch; however, there is a slight divergence between these sequences and the SGS analysis allows to demonstrate that there is a true intermingling of the sequences, therefore evidencing a lack of compartmentalization.

NGS analysis of patient 10 first indicates, compared to the NGS data from patient $5 \mathrm{~A}$, that we can fully differentiate the HIV-1 isolates from both patients although they are of the same subtype (B subtype); focusing again on patient 10 , we can draw the same conclusion, as for patient $5 \mathrm{~A}$, on the low genetic divergence of the sequences between both compartments; when analysing the SGS data, the clonal PBMC sequences are located at the origin of the GALT NGS part of the tree, then found in the PBMC part of the NGS tree while GALT clonal sequences are located at the end of the GALT tree and the origin of the PBMC tree; as for patient $5 \mathrm{~A}$ we can conclude that there is no evidence of compartmentalization.

To confirm that all the sequences were clustered by patient, we estimated the evolutionary divergence between sequences (Table 1 ) considering patients $5 \mathrm{~A}$ and 10. HIV-1 clusters were identified at maximum genetic distances between 4.5 and $7.5 \%$ and bootstrap support threshold varied between 70 and 99\% [23]. As sequences from patients $5 \mathrm{~A}$ and 10 are assembled with a median divergence of $5.3 \%$ and $2.2 \%$ respectively with bootstrap values of $80 \%$ and $93 \%$, we confirm that these sequences from GALT and PBMC formed a specific cluster per patient.

\section{Discussion}

Archived viral DNA is found in intestinal tissue at a higher concentration than in PBMCs in ART patients [24], although the distribution of DNA in CD4+ CCR7 +, transitional memory and effector memory CD4 $+\mathrm{T}$ cells is different in blood and intestinal compartments [25]. GALT is therefore a compartment of major importance 


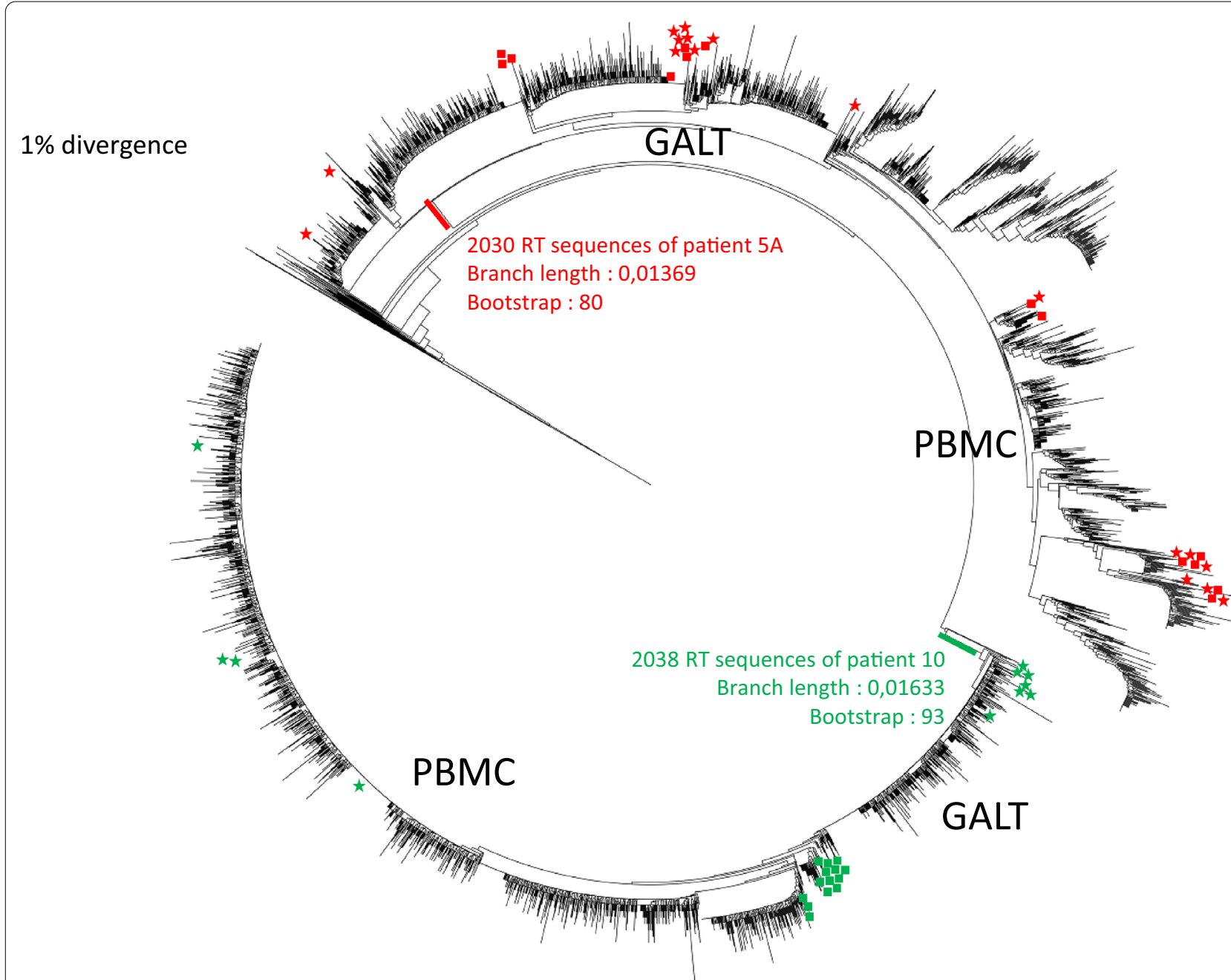

Fig. 1 Phylogeny of RT sequences of PBMC and GALT from patients 5A and 10. The NGS sequences are in black. SGS: the symbols denote sampling location and patients: patient 5A PBMC (red star), patient 5A GALT (red square), patient 10 PBMC (green star), patient 10 GALT (green square)

in the pathophysiology of HIV infection [26, 27]. The data presented here are not related to the quantification of archived DNA but rather to a comparison of the RT sequences obtained by NGS in GALT and PBMC. In that regard, Van Marle et al. [28] have studied biopsies from infected untreated individuals and sequenced the nef and RT genes of the viral RNA from blood (PBMC) and different parts of the gut by cloning and Sanger sequencing; they concluded that there is a compartmentalization of the virus in the gut reservoir. On the other hand, Lerner et al. [29] found a low diversity of the GALT and PBMC viruses in patients having experienced a voluntary treatment interruption while Imamichi et al. [30] did not demonstrate any difference between RNA and DNA sequences from gut and blood of patients chronically infected with HIV-1. Studying HIV-1 infected patients at early and chronic infection stages, Rozera et al. [31] found a more pronounced compartmentalization of proviral quasispecies in gut compared with PBMC samples in patients with early infection compared with chronic patients. The loss of gut/PBMC compartmentalization in more advanced stages of HIV infection was confirmed by longitudinal observation.

Regarding ART treated patients, Evering et al. [32] have studied the variability of the proviral DNA in the gut and blood compartments by SGS of the env part of the virus. They showed absence of evolution of the env sequences in the GALT and in PBMC; the authors mention that they cannot rule out the possibility of evolution in other viral genomic regions of HIV-1 such as pol which have not been investigated. Josefsson et al. [33] have compared the HIV DNA in PBMC and GALT from patients being 
Table 1 Estimates of evolutionary divergence between patients' HIV-1 proviral DNA sequences

\begin{tabular}{|c|c|c|c|c|c|c|}
\hline & \multicolumn{2}{|l|}{ Patient 5A } & \multicolumn{2}{|l|}{ Patient 10} & \multicolumn{2}{|l|}{ Patients $5 A+10$} \\
\hline & Median [min-max] & Mean & Median [min-max] & Mean & Median [min-max] & Mean \\
\hline \multicolumn{7}{|l|}{ GALT } \\
\hline NGS & 0.030 [0-0.189] & 0.029 & 0.016 [0-0.098] & 0.016 & nd & nd \\
\hline SGS & 0.055 [0-0.088] & 0.047 & $0.005[0-0.013]$ & 0.005 & nd & nd \\
\hline $\mathrm{NGS}+\mathrm{SGS}$ & $0.061[0-0.119]$ & 0.054 & $0.011[0-0.065]$ & 0.012 & nd & nd \\
\hline \multicolumn{7}{|l|}{ PBMC } \\
\hline NGS & $0.053[0-0.145]$ & 0.051 & $0.013[0-0.061]$ & 0.013 & nd & nd \\
\hline SGS & $0.047[0-0.122]$ & 0.051 & $0.013[0-0.030]$ & 0.013 & nd & nd \\
\hline $\mathrm{NGS}+\mathrm{SGS}$ & $0.065[0.013-0,132]$ & 0.065 & $0.016[0-0.057]$ & 0.017 & nd & nd \\
\hline \multicolumn{7}{|l|}{ GALT+PBMC } \\
\hline NGS & $0.053[0.008-0.143]$ & 0.054 & $0.022[0.003-0.095]$ & 0.022 & $0.08[0.047-0.214]$ & 0.085 \\
\hline
\end{tabular}

Evolutionary divergences are based on the number of base substitutions per site among RT NGS and/or SGS sequences obtained from GALT and/or PBMC proviral DNA of patients $5 \mathrm{~A}$ and 10

nd not done, $R T$ reverse transcriptase, GALT gut associated lymphoid tissue, PBMC peripheral blood mononuclear cells, NGS next generation sequencing, SGS single genome sequencing

on successful ART; they have used SGS technology and showed that there is no significant difference between the sequences from both compartments. They concluded that the HIV reservoir is stable on long-term suppressive ART and raise the hypothesis that the population of infected cells exhibiting a low variability of the virus could be maintained by homeostatic cell proliferation.

The patients of our study are similar to those of the two publications mentioned above i.e., ART- treated patients with controlled viral load and therefore a stable viral reservoir; the phylogenetic inferences obtained after NGS evidenced a very low genetic distance between the GALT and PBMC compartments intra-patient. On the other hand, it is possible to differentiate the GALT/ PBMC sequences inter-patients; the SGS analysis performed plus the genetic divergence values after NGS and SGS are concordant with a high similarity between proviruses intra-patient. It must be underlined that the SGS technique decreases taq-induced recombination and nucleotide mis-incorporation, providing therefore a more reliable conclusion than conventional cloning [20].

Among the limitations of our study, we must note the fact that only the RT part of the proviral DNA has been considered and also that we have analyzed global archived DNA molecules without differentiating noninfectious and replication competent genomes [34]; however, more recent data show that even defective proviral DNA molecules can be expressed and yield viral proteins recognized by CTL T CD8 + lymphocytes [35].

In conclusion, our results confirm that the proviruses in GALT and PBMC are very similar in these patients under ART and who could be the target population of choice for a therapeutic vaccine and indicate that the analysis of the blood compartment can provide results that can extrapolated to the gut compartment, a major reservoir of HIV.

The strategies used in the future, whether they will be associated with a shock-and-kill approach (and a therapeutic vaccine is a part of this approach) or block-andlock effect based on HIV silencing [36], will have to consider the proviral DNA of the archived virus not only in the blood but also in different tissue reservoirs including the gut.

\section{Abbreviations}

HIV: Human immunodeficiency virus; SIV: Simian immunodeficiency virus; ART: Antiretroviral therapy; GALT: Gut associated lymphoid tissue; NGS: Next generation sequencing; PBMC: Peripheral blood mononuclear cells; SGS: Single genome sequencing; Pol: Polymerase; RT: Reverse transcriptase; ART: Antiretroviral therapy; ITOL: Interactive tree of life; MEGA: Molecular evolutionary genetics analysis.

\section{Acknowledgements}

We thank Lucie Richard, an engineering student at the university of Bordeaux, for her excellent technical collaboration. The valuable advices and comments by Z Brumme (British Columbia Centre for Excellence in HIV/AIDS, Vancouver, BC, Canada) were greatly appreciated. We would like to thank Maria Fraraccio for her administrative support in Montreal and Fredéric Perry for his administrative assistance at the DRCI CHU in Bordeaux. Ray Cooke is also thanked for copyediting.

\section{Authors' contributions}

HF designed the study, found the main source of funding (MSD Avenir) and wrote the manuscript with the help of PP and contributions from PA and JPR; JPR recruited the patients; PP and AG executed technical parts of the study and were involved in analysis of the data. All authors read and approved the final manuscript.

\section{Funding}

The study was funded by a grant from MSD Avenir (DS-2016-005) and a financial contribution from GERMATAN (Groupe d'Etude et de Recherche sur les Maladies Animales Transmissibles et les Anthropozoonoses). Sequencing of proviral DNA by Illumina technology was performed at the Genome 
Transcriptome Facility in Bordeaux (grants from the Conseil Régional d'Aquitaine n 20030304002FA and 20040305003FA, from the European Union FEDER n 2003227 and from Investissements d'Avenir ANR-10-EQPX-16-01).

\section{Availability of data and materials}

The NGS sequences are available in GenBank under accession number PRJN557560; the Sanger sequences of the SGS study are available in GenBank under accession numbers MN250226 to MN250287.

\section{Declarations}

\section{Ethics approval and consent to participate}

This study using colon biopsies and blood from patients living with HIV $(\mathrm{PLWH})$ was approved by the Research Ethics Boards of the Research Institute of McGill University Health Centre (MUHC), Montreal, QC, Canada and the Centre Hospitalier de l'Université de Montréal (CHUM) Research Centre, Montréal, QC, Canada. The study also received approval from the Comité d'Ethique du Sud Ouest et Outremer (DC 2012/48) and was conducted in accordance with the Declaration of Helsinki. Each participant provided written informed consent before any study procedure.

\section{Consent for publication}

NA

\section{Competing interests}

The authors declare that they have no competing interests.

\section{Author details}

${ }^{1}$ CNRS UMR 5234, Université de Bordeaux, Bordeaux, France. ${ }^{2}$ Centre Hospitalier Universitaire de Montreal (CHUM) Research Centre, Montréal, QC, Canada. ${ }^{3}$ Département de Microbiologie, Infectiologie Et Immunologie, Faculté de Médecine, Université de Montréal, Montréal, QC, Canada. ${ }^{4}$ Chronic Viral IIIness Service and Division of Hematology, McGill University Health Centre, Montreal, QC, Canada. ${ }^{5} \mathrm{CHU}$ de Bordeaux, Bordeaux, France.

Received: 22 October 2020 Accepted: 15 March 2021

Published online: 23 March 2021

\section{References}

1. Chun T-W, Stuyver L, Mizell SB, Ehler LA, Mican JA, Baseler M, Lloyd AL, Nowak MA, Fauci AS. Presence of an inducible HIV-1 latent reservoir during highly active antiretroviral therapy. Proc Natl Acad Sci USA. 1997;94:13193-7.

2. Chun T-W, Justement JS, Murray D, Hallahan CW, Maenza J, Collier AC, Sheth PM, Kaul R, Ostrowski M, Moi S, Kovacs C, Fauci AS. Rebound of plasma viremia following cessation of antiretroviral therapy despite profoundly low levels of HIV reservoir: implications for eradication. AIDS. 2010;24:2803-8

3. Finzi D, Hermankova M, Pierson T, Carruth LM, Buck C, Chaisson RE, Quinn TC, Chadwick K, Margolick J, Brookmeyer R, Gallant J, Markowitz $M, H o$ DD, Richman DD, Siliciano RF. Identification of a reservoir for HIV-1 in patients on highly active antiretroviral therapy. Science. 1997;278:1295-300.

4. Chun T-W, Fauci AS. Viral persistence in HIV infection: much known, much to learn. J Infect Dis. 2013;208:1356-8.

5. Chun T-W, Moir S, Fauci AS. HIV reservoirs as obstacles and opportunities for an HIV cure. Nat Immunol. 2015;16:584-9.

6. Wong JK, YukI SA. Tissue reservoirs of HIV. Curr Opin HIV AIDS. 2016;11:362-70.

7. Barton K, Winckelmann A, Palmer S. HIV-1 reservoirs during suppressive therapy. Trends Microbiol. 2016;24:345-55.

8. Miller RL, Ponte R, Jones BR, Kinloch NN, Omondi FH, Jenabian M-A, Dupuy FP, Fromentin R, Brassard P, Mehraj V, Chomont N, Poon AFY, Brumme ZL, Routy J-P, The ORCHID Study Group. HIV diversity and genetic compartmentalization in blood and testes during suppressive antiretroviral therapy. J Virol. 2019. https://doi.org/10.1128/JVI.00755-19.
9. Mattapallil JJ, Douek DC, Hill B, Nishimura Y, Martin M, Roederer M. Massive infection and loss of memory CD4 + T cells in multiple tissues during acute SIV infection. Nature. 2005;434:1093-7.

10. Chun T-W, Nickle DC, Justement JS, Meyers JH, Roby G, Hallahan CW, Kottilil S, Moir S, Mican JM, Mullins JI, Ward DJ, Kovacs JA, Mannon PJ, Fauci AS. Persistence of HIV in gut-associated lymphoid tissue despite long-term antiretroviral therapy. J Infect Dis. 2008;197:714-20.

11. Estes JD, Kityo C, Ssali F, Swainson L, Makamdop KN, Del Prete GQ, Deeks SG, Luciw PA, Chipman JG, Beilman GJ, Hoskuldsson T, Khoruts A, Anderson J, Deleage C, Jasurda J, Schmidt TE, Hafertepe M, Callisto SP, Pearson H, Reimann T, Schuster J, Schoephoerster J, Southern P, Perkey K, Shang L, Wietgrefe SW, Fletcher CV, Lifson JD, Douek DC, McCune JM, Haase AT, Schacker TW. Defining total-body AIDS-virus burden with implications for curative strategies. Nat Med. 2017;23:1271-6.

12. Deeks SG, Lewin SR, Ross AL, Ananworanich J, Benkirane M, Cannon P, et al. International AIDS society global scientific strategy: towards an HIV cure. Nat Med. 2016;22:839-50.

13. Fleury $H$, Tumiotto $C$, Bellecave $P$, Recordon-Pinson P. Therapeutic vaccine against HIV, viral variability, cytotoxic T lymphocyte epitopes, and genetics of patients. AIDS Res Hum Retrovir. 2018;34:27-30.

14. Tumiotto $C$, Alves BM, Recordon-Pinson P, Jourdain M, Bellecave P, Guidicelli G-L, Visentin J, Bonnet F, Hessamfar M, Neau D, Sanchez J, Brander C, Sajadi M, Eyzaguirre L, Soares EA, Routy JP, Soares MA, Fleury H. Provir/ latitude 45 study: a step towards a multi-epitopic CTL vaccine designed on archived HIV-1 DNA and according to dominant HLA I alleles. PLoS ONE. 2019;14:e0212347.

15. Gosselin A, Wiche Salinas TR, Planas D, Wacleche VS, Zhang Y, Fromentin R, Chomont N, Cohen EA, Shacklett B, Mehraj V, Ghali MP, Routy JP, Ancuta P. HIV persists in CCR6 + CD4 + T cells from colon and blood during antiretroviral therapy. AIDS. 2017;31:35-48.

16. Ode H, Matsuda M, Matsuoka K, Hachiya A, Hattori J, Kito Y, Yokomaku Y, Iwatani Y, Sugiura W. Quasispecies analyses of the hiv-1 near-full-length genome with illumina MiSeq. Front Microbiol. 2015;6:1258.

17. Alves BM, Siqueira JD, Garrido MM, Botelh OM, Prellwitz IM, Ribeiro SR, Soares EA, Soares MA. Characterization of HIV-1 near full-length proviral genome quasispecies from patients with undetectable viral load undergoing first-line HAART therapy. Viruses. 2017;9:E392.

18. Bellecave $\mathrm{P}$, Recordon-Pinson $\mathrm{P}$, Fleury $\mathrm{H}$. Evaluation of automatic analysis of ultradeep pyrosequencing raw data to determine percentages of HIV resistance mutations in patients followed-up in hospital. AIDS Res Hum Retrovir. 2016;32:85-92.

19. Letunic I, Bork P. Interactive tree of life (iTOL) v3: an online tool for the display and annotation of phylogenetic and other trees. Nucleic Acids Res. 2016;44:W242-5.

20. Palmer S, Kearney M, Maldarelli F, Halvas EK, Bixby CJ, Bazmi H, Rock D, FalIoon J, Davey RTJ, Dewar RL, Metcalf JA, Hammer S, Mellors JW, Coffin JM. Multiple linked human immunodeficiency virus type 1 drug resistance mutations in treatment-experienced patients are missed by standard genotype analysis. J Clin Microbiol. 2005;43:406-13.

21. Tamura K, Nei M, Kumar S. Prospects for inferring very large phylogenies by using the neighbor-joining method. Proc Natl Acad Sci USA. 2004;101:11030-5.

22. Kumar S, Stecher G, Tamura K. MEGA7: molecular evolutionary genetics analysis version 7.0 for bigger datasets. Mol Biol Evol. 2016;33:1870-4.

23. Ragonnet-Cronin M, Hodcroft E, Hué S, Fearnhill E, Delpech V, Brown AJ, Lycett S. UK HIV drug resistance database. Automated analysis of phylogenetic clusters. BMC Bioinform. 2013;14:317.

24. Moron-Lopez S, Puertas MC, Galvez C, Navarro J, Carrasco A, Esteve M, Manye J, Crespo M, Salgado M, Martinez-Picado J. Sensitive quantification of the HIV-1 reservoir in gut-associated lymphoid tissue. PLOS ONE. 2017;12:e0175899.

25. YukI SA, Shergill AK, Ho T, Killian M, Girling V, Epling L, Li P, Wong LK, Crouch P, Deeks SG, Havlir DV, McQuaid K, Sinclair E, Wong JK. The distribution of HIV DNA and RNA in cell subsets differs in gut and blood of. J Infect Dis. 2013;208:1212-20.

26. Thompson CG, Gay CL, Kashuba ADM. HIV persistence in gut-associated lymphoid tissues: pharmacological challenges and opportunities. AIDS Res Hum Retrovir. 2017;33:513-23.

27. Augustin M, Horn C, Ercanoglu MS, Bondet V, Suarez I, Chon S-H, Nierhoff D, Knops E, Heger E, Oette M, Klein F, Fätkenheuer G, Duffy D, MüllerTrutwin M, Lehmann C. Treasure hunt: HIV DNA in distinct subsets in the 
blood, the terminal ileum, and rectum. Conference on Retroviruses and opportunistic infections. Seattle, USA. 2019. Abstract 335.

28. van Marle G, Gill MJ, Kolodka D, McManus L, Grant T, Church DL. Compartmentalization of the gut viral reservoir in HIV-1 infected patients. Retrovirology. 2007;4:87.

29. Lerner P, Guadalupe M, Donovan R, Hung J, Flamm J, Prindiville T, Sankaran-Walters S, Syvanen M, Wong JK, George MD, Dandekar S. The gut mucosal viral reservoir in HIV-infected patients is not the major source of rebound plasma viremia following interruption of highly active antiretroviral therapy. J Virol. 2011;85:4772-82.

30. Imamichi H, DeGray G, Dewar RL, Mannon P, Yao M, Chairez C, Sereti I, Kovacs JA. Lack of compartmentalization of HIV-1 quasispecies between the gut and peripheral blood compartments. J Infect Dis. 2011;204:309-14.

31. Rozera G, Abbate I, Vlassi C, Giombini E, Lionetti R, Selleri M, Zaccaro P, Bartolini B, Corpolongo A, D'Offizi G, Baiocchini A, Del Nonno F, Ippolito G, Capobianchi MR. Quasispecies tropism and compartmentalization in gut and peripheral blood during early and chronic phases of HIV-1 infection: possible correlation with immune activation markers. Clin Microbiol Infect. 2014;20:157-66.

32. Evering TH, Mehandru S, Racz P, Tenner-Racz K, Poles MA, Figueroa A, Mohri H, Markowitz M. Absence of HIV-1 evolution in the gut-associated lymphoid tissue from patients on combination antiviral therapy initiated during primary infection. PLoS Pathog. 2012;8:e1002506.
33. Josefsson L, von Stockenstrom S, Faria NR, Sinclair E, Bacchetti P, Killian M, Epling L, Tan A, Ho T, Lemey P, Shao W, Hunt PW, Somsouk M, Wylie W, Douek DC, Loeb L, Custer J, Hoh R, Poole L, Deeks SG, Hecht F, Palmer S. The HIV-1 reservoir in eight patients on long-term suppressive antiretroviral therapy is stable with few genetic changes over time. Proc Natl Acad Sci USA. 2013;110:E4987-96.

34. Bruner KM, Murray AJ, Pollack RA, Soliman MG, Laskey SB, Capoferri AA, Lai J, Strain MJ, Lada SM, Hoh R, Ho Y-C, Richman DD, Deeks SG, Siliciano ID, Siliciano RF. Defective proviruses rapidly accumulate during acute HIV-1 infection. Nat Med. 2016;22:1043-9.

35. Pollack RA, Jones RB, Pertea M, Bruner KM, Martin AR, Thomas AS, Capoferri AA, Beg SA, Huang S-H, Karandish S, Hao H, Halper-Stromberg E, Yong PC, Kovacs C, Benko E, Siliciano RF, Ho Y-C. Defective HIV-1 proviruses are expressed and can be recognized by cytotoxic $T$ lymphocytes which shapes the proviral landscape. Cell Host Microbe. 2017:21:494-50636.

36. Vansant G, Bruggemans A, Janssens J, Debyser Z. Block-and-lock strategies to cure HIV infection. Viruses. 2020;12:84.

\section{Publisher's Note}

Springer Nature remains neutral with regard to jurisdictional claims in published maps and institutional affiliations.
Ready to submit your research? Choose BMC and benefit from:

- fast, convenient online submission

- thorough peer review by experienced researchers in your field

- rapid publication on acceptance

- support for research data, including large and complex data types

- gold Open Access which fosters wider collaboration and increased citations

- maximum visibility for your research: over $100 \mathrm{M}$ website views per year

At BMC, research is always in progress.

Learn more biomedcentral.com/submissions 